Meta

Journal des tradlucteurs

Translators' Journal

\title{
Contrastive and translational issues in rendering the English progressive form into Spanish and Catalan: an informant-based study
}

\section{Anna Espunya}

Volume 46, numéro 3, septembre 2001

URI : https://id.erudit.org/iderudit/002710ar

DOI : https://doi.org/10.7202/002710ar

Aller au sommaire du numéro

Éditeur(s)

Les Presses de l'Université de Montréal

ISSN

0026-0452 (imprimé)

1492-1421 (numérique)

Découvrir la revue

Citer cet article

Espunya, A. (2001). Contrastive and translational issues in rendering the English progressive form into Spanish and Catalan: an informant-based study. Meta, 46(3), 535-551. https://doi.org/10.7202/002710ar
Résumé de l'article

Cette contribution présente les correspondances formelles du progressif anglais dans des traductions de l'anglais à l'espagnol et au catalan. Un intérêt particulier est porté au choix entre les formes simples et les formes progressives. Son approche méthodologique inclut la participation d'informants aussi bien comme traducteurs que comme critiques de traductions publiées. Cette étude analyse les facteurs internes à la langue et les facteurs en relation avec la consigne de traduction qui déterminent le choix de formes verbales. 


\title{
Contrastive and translational issues in rendering the English progressive form into Spanish and Catalan: an informant-based study:
}

\author{
ANNA ESPUNYA \\ University Pompeu Fabra, Barcelona, Spain
}

\begin{abstract}
RÉSUMÉ
Cette contribution présente les correspondances formelles du progressif anglais dans des traductions de l'anglais à l'espagnol et au catalan. Un intérêt particulier est porté au choix entre les formes simples et les formes progressives. Son approche méthodologique inclut la participation d'informants aussi bien comme traducteurs que comme critiques de traductions publiées. Cette étude analyse les facteurs internes à la langue et les facteurs en relation avec la consigne de traduction qui déterminent le choix de formes verbales.
\end{abstract}

\section{ABSTRACT}

This is a study on the formal correspondences for the English progressive in translations from English to Spanish and Catalan, with a special focus on the choice between simple and progressive forms. Its methodological approach includes the participation of informants both as translators and as evaluators of published translations. The paper discusses both the language-internal and task-related factors that play a role in the choice of verb forms.

\section{MOTS-CLÉS/KEYWORDS}

calque, descriptive translation studies, linguistics for translation, literal translation, progressive forms

\section{Introduction}

This paper presents the results of a study on the formal correspondences for a particular linguistic form, namely the English progressive, in translations from English to Spanish and Catalan. The study was conducted with two goals in mind, a pedagogical one and a descriptive/theoretical one. The pedagogical aim was finding in real translation products those linguistic devices capable of rendering in Spanish and Catalan the semantic and discourse content of the English progressive. The descriptive-theoretical aim was to see what factors related to the translator and the translation process played a role in the choice of those forms.

The progressive is a good case for testing aspects of linguistic contrast and the scope of prescriptive notions that affect the performance of translators. As far as linguistic contrast between present-day English and the two Western Romance languages is concerned, it is a well-known fact that in English the only inflected verb form which unmarkedly expresses the actuality or currency of an event at a given reference moment is the progressive form be $+\mathrm{V}$-ing. In Spanish and Catalan two forms are available to express this aspectual-temporal notion: the simple tense form (bearing inflectional morphology) and a periphrastic verb combination consisting of 
the inflected form of the verb estar followed by the gerund of the verb with lexical content. Any translator faced with the need to render (1a) in Spanish has two options, (1b) and (1c):

(1) a. Now the baby girl is playing with her new toy.

b. Ahora la niña juega con su nuevo juguete.

c. Ahora la niña est· jugando con su nuevo juguete.

From the example above, one might be tempted to infer that Spanish estar + gerund is fully equivalent to English be $+\mathrm{V}$-ing as well as synonymous with the Spanish simple form, but things are somewhat more complex. To begin with, in English the distinction progressive vs. simple has grammatical status (Quirk and Greenbaum 1973) and be + V-ing is considered part of the verbal paradigm. ${ }^{1}$ In Spanish and Catalan, in contrast, aspect as a grammatical category is not based on the distinction progressive vs. simple but on the perfective vs. imperfective distinction so estar + gerund is not considered part of the verbal paradigm. Secondly, the two Romance forms stand in full semantic contrast in certain contexts, essentially the same ones where English simple and progressive forms form minimal pairs. ${ }^{2}$

Traditional grammar classifies estar + gerund as a member of the set of the socalled periphrases, accessory lexical devices which express a considerable range of aspectual distinctions. In particular, estar + gerund is described as the form that highlights the continuousness of a process or the development of a series of events. ${ }^{3}$ Furthermore, the use of estar + gerund seems to carry greater subjectiveness than the use of the simple form (e.g., see Roca Pons 1958: 30). Scholars often describe its effects as intensifying (Wandruszka 1976: 522 and 528; Gómez-Torrego 1988: 140). Unfortunately, no precise definition of the term is provided and a broad range of semantic and pragmatic notions are characterised as intensifying readings-from aspectual ones such as iteration to modal ones such as impatience, effort or difficulty entailed by a given action (see, among others, Gómez-Torrego 1988 and García González 1992). In certain discourse situations, especially in conversation, the pragmatic adequacy of estar + gerund vs. the simple form depends on the speaker's presuppositions, the knowledge shared with the hearer, and the familiarity or recent acquaintance with discourse topics. In sum, simple form and "durative periphrasis" are not fully interchangeable in Spanish or Catalan.

The previous paragaph describes a static situation. But language is in constant change. Prescriptivist grammarians of Spanish and Catalan have long been aware of an increase in the frequency of estar + gerund, apparently at the expense of the simple form, whose functions it seems to be taking over. They blame the influence of English through translations (a form of language contact). According to this hypothesis, given the influence of translated texts in the Spanish media today, the presence of estar + gerund as a frequency calque (i.e., a violation of the frequency patterns of a TL item) affects not only the text where it appears (causing it to depart from the norm of Spanish and Catalan and therefore reading as a translation) but also the source languages themselves in that it creates a new norm of usage. The consequence is that translation handbooks and style reference works warn against estar + gerund.

The trend seems to have diachronic roots as well, which means that the use of estar + gerund need not be considered a calque from English. Vañó-Cerdá (1982) reports the extension of estar (winning over ser) as attributive copula. It seems plau- 
sible that the spread of the copula estar would foster that of estar + gerund. What we know about estar + gerund is that it is the product of a grammaticalisation process which started in the Late Latin period, when it was introduced as a calque from Greek. In a grammaticalisation process, the new form takes over a function that was performed by some other form or an altogether new function. Alarcos Llorach (1994) characterises the simple present tense of Spanish not as a present tense marker but as a temporally neutral or atemporal form (since it may express, besides simultaneity, anteriority and posteriority with respect to a reference point more or less located in the present). In this view, estar + gerund "has been considered the true expression of the present tense thanks to its currency, concreteness, value, as opposed to the atemporality of the simple present." (reported in García González 1992: 50 , my translation and my emphasis). The argument that grammaticalisation processes can affect the meaning of verb forms is supported in Squartini (1995), where it is shown that the Italian periphrasis stare + gerund is specializing as an imperfective marker, the last step in a path that goes from locative through durative through imperfective progressive.

As we can see, the fact that there are various sources of variation affecting the distinction estar + gerund vs. the simple form in Spanish and Catalan makes the translation of the progressive a good test item. Linguistic variation in the target languages, together with the fact that some of the readings of the English progressive form (essentially modalised readings) are not expressed by estar + gerund, make it easy to predict that in translating there will be cases where the choice of estar + gerund as the translation of the English progressive will lead to unintended shifts in the meaning of the target fragment (semantic calque), to an unnaturally higher frequency of ocurrence of the form (frequency calque), or to an avoidance strategy.

There are several ways to approach the study of linguistic form in translation. Generally, when linguistic items display a stable behaviour, scholars compare their correspondences in a translated version of an original text to see if the translation preserves semantic and discourse equivalence while complying with the rules of the target language (see, for instance the study on the translation of the present perfect by Kaskin 1998). But those cases where the target language is undergoing variation seem to call for the comparison of more than one version of the same original text in order to test the extent of such variation. Furthermore, it seems reasonable to have more than one source of judgement on the acceptability of the correspondences. For this reason, the data have been gathered with the help of informants.

\section{About the study}

\subsection{The corpus}

For a study of the correspondence given to a verb form we needed a corpus of source text (ST) and target text (TT) pairs with a considerable degree of formal parallel between them. The texts chosen for the study belonged to the genre of press editorials translated for "press review" sections of other periodicals. ${ }^{4}$

The original editorials were published in the U.S. daily newspapers New York Times or Washington Post and their translated versions in the Spanish daily El Pais or the Catalan daily Avui, in a section devoted to reproducing (fragments of) editorials 
published by other newspapers, foreign or national. The translated text appears to be quoting verbatim the original text. ${ }^{5}$

The texts given to the informants were chosen from a corpus built between 1996 and 1998 of editorials which contained instances of the progressive form that had been translated in various ways. The texts selected for the study were representative of different contexts of use which could be expected to trigger different reactions from informants. Thus there were the following items: an instance of a clear-cut linguistic contrast between English and Spanish in the use of the progressive (the simple form was expected as the grammatically correct correspondence); an instance of a form often translated as estar + gerund even if the normativist literature on Spanish warns that it is a calque from English; an item which was translated by a different tense form in the published version responding to what seems to be a contrast between English and Spanish in the aspectual perspective. Finally, there were two instances of contexts which allowed a certain degree of free choice between simple and progressive form.

\subsection{About the methodology}

The data for our analysis were the range of forms used as correspondences to the English progressive. This justifies a comparative study, i.e. contrasting the published translation with other versions of the same text produced by a group of informants. An additional source of information was provided by the evaluation of the published solutions by the same set of informants in the role of evaluators. The comparative approach is especially relevant since some of the contexts allow for a substantial degree of free variation between simple and progressive forms.

Two types of tasks were set up to elicit information from the informants (eight lecturers of the Universitat Pompeu Fabra's translation school in Barcelona, four per language pair, referred to in the discussion by means of capital letters from A to D (English-Spanish) and from E to $\mathrm{H}$ (English-Catalan). Most of the examples discussed in this paper, however, will be drawn from the English-Spanish group). A group of texts (chosen according to the criteria discussed in the following subsection) was divided into two halves and so were the informants for each language pair. As the first task, whose goal was to see how much variability there could be in the correspondences found for the progressive forms, the two pairs of informants were given a small translation activity. They had to read the whole text (to gain enough familiarity with the topic from the context and to become aware of any discourse factors influencing the choice of the tense form), and subsequently read and translate a sentence which contained a progressive form from each text. The form was not marked in any way and they had not been told about the purpose of the study beforehand. Obviously, a tense form is just one of a sentence's many components. By asking the informants to translate the whole sentence rather than only the verb form, the task was a translation task rather than a language competence task. Informants were asked to provide as literal a translation as possible though their products were to remain within the boundaries of grammaticality and naturalness. Literalness was related to the purpose of the translated text, i.e. to reproduce the content of the foreign articles preserving the structure and the lexical formulation of the original as fas as the target language allowed it. This is literal translation in Catford's (1965: 25) 
terms, i.e. a word-for-word strategy allowing for changes where the grammar of the TL requires them. Also in Nord (1994: 93) literal translation is the strategy used for documenting a communication that has occurred in the source culture for readers of the target culture. Specifically, the strategy consists in reproducing the form of the original text paying attention to lexical units of the ST. Newmark (1988: 63) uses instead the label semantic translation to name the "the attempt to render, as closely as the semantic and syntactic structures of the target language allow, the exact contextual meaning of the original."

In the second part of the experiment, informants were asked to evaluate the correspondences found to the English progressive forms by the translator of the published versions. Each pair of informants evaluated the excerpts that they had not translated previously. The informants are skilled translators and, as lecturers and members of the academic community, they are used to formulating criteria and evaluating products of other people, be they translators or students. The evaluation task was guided by four questions. The informants had to provide their judgements on the semantic (i.e. tense, aspect, modal, discourse) accuracy, the grammatical accuracy and the stylistic quality of the solution. They were also asked to provide judgements according to criteria of their own, if they felt the first three were insufficient. After the second task I conducted a brief interview where I asked them about how they deal with this linguistic form in their lectures and course-design, and whether they had the notion that estar + gerund was susceptible of overuse.

The judgements of informants as native TL-speakers and in the role of actual readers of the translated text were intended to corroborate the existence and the extent of variability in the grammar and the norm of the target language, although, as we will see, variability also arose in the translation styles.

Two warnings are in order. Firstly, this study was obviously not intended as a quantitative study but rather as an extended case study that may allow us to identify the issues that would need to be addressed by a large-scale project. Secondly, even if data are derived from the participation of informants, the focus was not on the psychological process of translation, and the informants were not asked to submit think-aloud protocols of their activity but just to provide answers to specific questions.

\section{Discussion}

As far as the English-Spanish part of the study is concerned, the raw quatitative data are the following: Firstly, where the form estar + gerund clearly did not express the meaning of the English progressive, none of the 4 informants used it. Instead they used the simple form. Secondly, where the correspondence English progressive into estar + gerund has traditionally been considered a calque in the normative literature, it is used or approved of by only 1 informant out of 4 . Thirdly, where the correspondence was subject to free variation ( 2 instances), estar + gerund was used by 1 informant out of 4 in the first instance and by 2 out of 4 informants, in the second instance. This also included the instance where a change of semantic perspective was applicable.

Globally speaking, the results suggest that the informants as a group are not favouring the use of estar + gerund over the simple form. Looked at individually, the choices made by informants and the arguments used in their evaluation respond to a 
variety of factors, which I will try to analyse and discuss in this section. The presentation is organised according to the three correspondence patterns.

\subsection{The English progressive is translated as estar + gerund}

Given the formal parallel between the English and the Spanish forms and the difference in meaning/use/frequency, certain instances of this correspondence may be regarded as calques from English. The list of uses of estar + gerund that prescriptive works identify as non-native is not long. One of them is the combination of the progressive and the passive voice morphology, although there is disagreement on what type of calque it is.

In his book on anglicismos or calques from English, Lorenzo (1996: 19) briefly reports the long debate on the nature of this combination. At the root of the debate are the discrepancies on the criteria used by the two camps. Grammatically and morphologically speaking, the combination is possible in Spanish and in fact fills a gap left by the language's own evolution: the passive auxiliary ser has a gerund, siendo, which can be the second element of the progressive periphrasis and the auxiliary of the passive construction. Semantically speaking, it should be possible to understand a transitive action that is in progress from the perspective of the affected object instead of the agent while retaining the ongoing nature. So a word-for-word translation for $(2 \mathrm{a})$ is $(2 \mathrm{~b})$ :

(2) a. The ship sank when the passengers where still being rescued.

b. El barco se hundió cuando los pasajeros aún estaban siendo rescatados.

For those in one camp of the debate, these are sufficient arguments to accept estar + siendo + V-passive participle as a Spanish form (e.g., see Gómez Torrego 1988: 146), even if they do not grant it a fully "naturalised" status, as it is considered a source of frequency calques (e.g., see Lorenzo 1996: 119), i.e. its overuse in a text breaks the pattern of frequency of the gerund in Spanish texts.

For those in the opposite camp, the diachronic argument is stronger than the morphological and semantic ones. Since the combination is an innovation resulting from contact with English-through translations, the influence of English-speaking journalism and news agencies, etc. (e.g., see Chris Pratt 1980), they refuse to grant it naturalised status.

As Lorenzo (1996) points out, the normative status of the combination has been subject to evolution. The extent to which a form previously considered a calque can become accepted by convention is best illustrated in the Manual de Español Urgente, a desktop reference grammar and stylebook which is updated yearly and which, though unofficially, has normative status among journalists and other members of the writing profession. Until its 9th edition-E.F.E. (1992)—, the combination was considered a "syntax" calque. In its 10th (1994) edition, it was no longer considered so. With these considerations in mind, let us now consider the following excerpt.

(3) The Vatican's words on its own measure of responsibility for the deaths of 6 million Jews during the Holocaust have been tensely awaited. [...] When it comes to the key matter of the relation between these [anti-Jewish] views and behavior during the Holocaust, "it may be asked whether the Nazi persecution of the Jews was not made easier by the anti-Jewish prejudices embedded in some Christian minds and hearts." Did Christians "give every possible assistance to those being persecuted?" 
[...] Al referirse al principal asunto, la relación entre estos puntos de vista y la conducta durante el tiempo del Holocausto, "quizás debería preguntarse si la persecución de los judíos no fue más fácil por los prejuicios antisemitas incrustados en algunas mentes y corazones católicos". "Hicieron los católicos todo lo posible por aquellos que estaban siendo perseguidos?"

Evaluators reject the combination as a violation of the norm in spite of its semantic accuracy, its grammaticality and the fact that its normative status has changed, at least for certain specialised languages such as the language of journalism. The solutions they suggest are predicator noun phrases such as objeto de persecución and victimas de la persecución which denote affected participants and therefore preserve the agent-patient distribution of the proposition. Similarly, one of the informanttranslators, translator $\mathrm{D}$, used the adjective of participial origin perseguidos instead of the relative clause. Translator $\mathrm{C}$, however, used the same form as in the published translation, i.e. estaban siendo perseguidos.

Note that the NP or AP solutions are clearly more economical than the clausal version. Given that Spanish translated versions tend to have more words than their English originals, it is not unreasonable to speculate that translators who were aware of this fact would actually want to use such a syntactic strategy to keep down the number of words. On the other hand, the translators who used estar + gerund may have been aware that the combination appears frequently in the language of journalism and so used it as a marker of genre, regardless of its normative status.

There are contexts where both the simple and the progressive form seem to be adequate. To test the informants' criteria, the task sheet included two items, each with a distinct form. Text (4) is the estar + gerund instance.

(4) In the 80s, much of South America's change was obscured in the American view by Central America's leftist insurgencies and rightist repression and the various political currents they stirred in the United States. But those days are gone, and now the region is, in full view, widening and trying to deepen its hold on the institutions of market democracy. (WP13-10-97)

Durante los años ochenta, gran parte del cambio en Latinoamérica se vio oscurecido desde la perspectiva americana por las insurrecciones izquierdistas y la represión de la derecha en Centroamérica y las diferentes corrientes políticas que agitaron Estados Unidos. Pero esos días han pasado y la región está, en general, en expansión y tratando de reforzar su vinculación a las instituciones de la democracia de mercado. (EP14-10-97)

The paragraph establishes a contrast between two situations located in different periods of time. The adjunct in the 80s and the adverbial now separated by the clause But those days are gone provide the temporal reference. The first progressive form is widening is translated by transposition (a change in word class according to the classification of translation procedures by Vinay and Darbelnet 1958, 1995) as the PP en expansión. (an event-denoting noun). The second progressive form is translated by estar + gerund.

For evaluator A, the use of estar + gerund in this translation is not a calque. He follows the traditional view that what distinguishes the English from the Spanish progressive forms is that the latter always "intensify" the event. Since that intensifying value may not have been implicit in the original text, its addition could potentially cause some sort of semantic inaccuracy. In this text, however, the presence of the 
word trying, implying 'effort to achieve something', justifies the use of the periphrastic form for this informant.

Evaluator B considered the use of estar + gerund a frequency calque because it is part of a construction that follows patterns of sentence connection more frequent in English than in Spanish. She argued that the sentence would be "less clumsy" if the two events were linked through subordination (e.g. by means of the conjunction mientras 'while', explicitly durational in its aspectual character) instead of coordination. Spanish is said to prefer hypotactic means to express semantic links between propositions (Vázquez Ayora 1977: 111-112). The verb form of the subordinated clause could then be the simple present.

Although evaluator B did not bring it up, there is a stylistic reason not to use the progressive form twice. The translator had to face the coordination of two -ing forms but in Spanish the co-occurrence of words with the same endings in a short sequence is considered inelegant. The existence of two lexical entries estar (auxiliary of the progressive periphrasis vs. copula) allowed the translator to preserve the coordination structure, a reasonable decision if the literalness criterion is understood in a strict sense.

The translators also showed mixed preferences. Whereas informant $\mathrm{C}$ uses estar + gerund, informant-translator D uses the simple form. Since this seems to be a context where both forms can be used, the choice of estar + gerund is subject to other considerations, although it may also be interpreted to reveal differences in the prejudices of different translators.

None of the instances discussed so far illustrate the adoption by the target form of a semantic/discourse function of the English form. Since it is relevant for the purposes of this paper to see one case, I have drawn one from the Catalan test items. Consider the following excerpt, specifically the second occurrence of the progressive form:

(5) Companies from various nations are pulling out due to negative publicity and the country's pervasive corruption. By showing that Washington is serious, President Clinton may now persuade other nations to demand change or join the exodus.

$[\ldots]$

The promotion of American business abroad has so dominated the Clinton foreign policy, especially in Asia, that repressive but wealthy countries no longer take Washington's statements about human rights and democracy seriously.

True, impoverished Burma is getting much tougher treatment than Indonesia and China, which are far more important trading partners.

Empreses de diversos països estan marxant a causa de la publicitat negativa i la creixent corrupció del país. Per demostrar que Washington és seriós, el president Clinton pot ara persuadir altres països a demanar el canvi o afegir-se al boicot.

$[\ldots]$

La promoció dels negocis americans a l'estranger ha dominat tant la política estrangera de Clinton, especialment a l'Àsia, que els països dictatorials més rics ja no es prenen les tesis americanes sobre els drets humans i la democràcia seriosament.

És veritat que l'empobrida Birmània està rebent un tractament molt més dur que Indonèsia i la Xina, els quals són socis comercials molt més importants dels EUA.

The excerpt belongs to an editorial supporting the decision taken by the President of the USA to enforce a law banning American investment in Burma as a response to 
the human rights violations in that country. It is arguable here that the English progressive form fulfills a specific discourse role called interpretive in König (1980) and denominating in Mélis (1997), where one event that has been previously introduced in the discourse is later referred to by another predicate in the progressive form. According to Mélis, it is a device for the writer to signal that he is willing to negotiate with his reader the denomination of the event. Note that in the case we are discussing, the clause where it occurs does not introduce a new event but refers to a previously introduced one. Secondly, the predicate getting much tougher treatment than Indonesia and China does not express a physical event or even a mental one; rather it equates economic sanctions (previously introduced as a topic) with a tough treatment. This sentence is evaluative, as the adjective tough and the comparative structure signal. The sentence states the paper's opinion, i.e. that the lack of enforcement of an investment ban on richer countries entails inequality of treatment for poorer countries. Certainly, evaluation or the expression of the paper's point of view is among the goals of editorials together with exposition and argumentation (Rivers et al. 1988).

This use of estar + gerund is not reported by descriptive grammars of Catalan. In the Catalan stylebook for film translators (Televisió de Catalunya 1995: 36) a similar discourse use is considered a calque. Instances with the features of denominative progressive occur in oral productions (such as interviews) as well as in their transcriptions on newspapers. ${ }^{6}$ Evaluators $\mathrm{E}$ and $\mathrm{F}$ found the simple form was preferrable. In particular, Evaluator F argues that estar + gerund is inadequate-I assume, semantically inadequate-because the sentence does not denote an ongoing event, especially since the main verb has "a passive sense". He also adduces a stylistic reason: the gerund rebent builds an internal rhyme with the noun tractament and, as was said before, internal rhymes are considered bad style in Catalan and Spanish. Although I think evaluator $\mathrm{F}$ is wrong in his assessment of the compatibility between a progressive perspective and a verb of affectedness, what I find most valuable is his realisation that there really is no event going on and the resulting opinion that this fact justifies the use of the simple form. This reveals that he obviously assigns no special discourse value to estar + gerund beyond the aspectual one.

Informant-translators confirm the status of the simple form as the normatively preferred form. Informant $\mathrm{G}$ used a passive in the present, És tractat amb molta més duresa 'is treated much more toughly'. Informant $\mathrm{H}$ used a simple form and otherwise translated the sentence word by word as rep un tracte molt més dur.

The informants are unanimous in their treatment of estar + gerund in the traditional way, i.e. as an aspectual periphrasis of lexical status with lexical restrictions. But the following question arises: if estar + gerund is incompatible with the affectedness verb receive, then why didn't the translator notice this? The lexical requirement is violated by the translator, which means his or her solution is a calque. It may well be, however, that the translator was sensitive to the discourse value of the English progressive and tried to reproduce it by using the word-for-word equivalence. 


\subsection{The English progressive is translated as the corresponding simple tense form}

There are cases where the Spanish simple form is the only form available to express the temporal or aspectual meaning of the English progressive form. For example, the combination of the progressive and an operator such as the future tense marker may vary in its readings from language to language. In English, the combination future + progressive locates the development of an event in the future, as in Spanish and Catalan, but in addition conveys present deontic modality, i.e. certainty in the present that a given event will take place in the future (implication that it has already been fixed or decided). In Spanish, when it conveys modality, it is epistemic rather than deontic (conjecture, possibility). Deontic modality is rather conveyed by the simple future and by the periphrastic sequence ir $+a+$ infinitive. Consider, for the sake of illustration, excerpt (6). ${ }^{7}$

(6) Mr. Clinton will be saying to Latins that the U.S. government is ready to cooperate in coming to terms with the global economy-with promotion of trade and investment and with protection of the individuals and social classes bruised by the process. He will also be equipping himself to bring back a more authoritative grip on the issue to an American Congress and public still deeply conflicted by it. [...]

Clinton asegurará a los latinoamericanos que su gobierno está preparado para cooperar en los términos de la economía global, con la promoción del gobierno y la inversión y con la protección de los individuos y las clases sociales contusionadas por el proceso. (published translation stops here).

The word-for-word option (estar + gerund in the future) is ruled out by the translator and also by the informants, both translators and evaluators, who tend to suggest or use the simple future. This indicates a clear contrast between English and Spanish. But there is more to be learned from the informant's reactions to this test item. For various reasons that seem unrelated to the choice of a tense form, the published solution was not found satisfactory by evaluators. According to evaluator C, there is a semantic component left unexpressed. At the root of the inaccuracy is the lexical choice asegurar 'assure', which changes the thematic or informational structure of the original. In the original, say is non-rhematic and serves to introduce the rheme of the sentence, the object of the saying that appears at clause-end position (Clinton's message). In contrast, asegurar is semantically richer than say and informationally stronger and so becomes part of the rheme. This seems to be the most prominent feature of the fragment for Evaluator $\mathrm{C}$, who proposed the translation El mensaje que Clinton transmitirá a los latinoamericanos es [...], by back translation 'the message that Clinton will be conveying to Latins is [...]'. Interestingly, if we focus on tense forms, a by-product of this solution is a change with respect to the original text: the tense of the main clause is not a future tense but a present tense, which carries the implication that the message is known by the reporter in the present. Tense is thus interrelated with information structure.

Evaluator D also noted the loss of the overtone of planning and suggested that the verb translating say should be included in modal (deontic) verbal expressions like tiene intención de and piensa 'intends to', both in the present. Evaluator D also judged the choice of asegurar? as inadequate, given the semantic neutrality of the original say. Note that both evaluators used a similar approach: they focus on specific 
lexical items that they find salient in the translation and build their conclusions from there.

Let us turn now to an instance where the simple form was in free variation with the periphrastic progressive form.

(7) President Bill Clinton's first trip to Latin America is not only a diplomatic catch-up. In its larger dimension it is designed to identify the United States with the forces of change that are sweeping furiously across South America. [...] "An Important Trip", WP13-10-97

El primer viaje de Bill Clinton a Latinoamérica no es únicamente una puesta al día de carácter diplomático. En su más amplia dimensión está diseñado para identificar a Estados Unidos con las fuerzas de cambio que se extienden vigorosamente por Latinoamérica [...] EP14-10-97

The simple form in Spanish expresses the actual event reading of the English progressive. ${ }^{8}$ Both evaluators of this excerpt found the present tense semantically accurate though insufficient to render the currency, recency and continuousness of the event. According to evaluator $\mathrm{C}$, the correspondence does not adequately express the idea that the phenomenon is relatively recent. To compensate for this semantic loss, she suggested the inclusion of a temporal adjunct such as en la actualidad 'currently' to anchor the process to the moment of writing. This judgement fits in with the view of the simple present as a form which no longer anchors events to the present moment but as an atemporal or at least temporally neutral form. Evaluator D suggested the inclusion of an adverbial expression such as sin cesar 'unceasingly' or constantemente 'constantly' to render the value of continuousness. It is significant, though, that neither of them suggested estar + gerund as a better option.

The informant-translators confirm this judgement. Translator A reformulated the syntactic structure where the progressive form occurred - a relative clause - and reformulated it as an adjective phrase. So the noun phrase the forces of change that are sweeping furiously was translated as las tremendas fuerzas de cambio presentes en SuramErica, by backtranslation 'the tremendous forces of change present in Southamerica'. The semantic content of the progressive form is adequately rendered by the adjective presentes. Note that this translator reshuffled the original's semantic components: the metaphorical component of sweep disappears and the adverbial furiously qualifying the intensity of the action is rendered as the adjective tremendas, a qualifier of the action's subject. The relevance of translator A's solution is that it uncovers another potential factor influencing on the choice of a given form: the degree of translational difficulty caused by the lexical choices of the original. The metaphorical use of sweep and furiously may have caught the attention of translator A and the solution to that problem may have determined the correspondence for the progressive form. In addition, this proposal also points at the limits of the literalness criterion when the translator faces metaphorical uses of words. Translator B tried a word-for-word solution as far as word class is concerned although her lexical choices depart from the metaphorical use of the original: are sweeping furiously becomes est. $n$ extendiĖndose con fuerza imparable, by back translation 'are spreading with unstoppable force'. 


\subsection{The English progressive is translated neither as the simple form nor as estar + gerund}

In this section the discussion turns to a tense choice reflecting change in the semantic perspective.

(8) The reason NATO enlargement could prove to be a mistake is best explained by comparing the decision before the Senate with the far different course that America chose at the end of World War II. America acted then not to isolate Germany and Japan, or to treat them as future threats, but rather to help them make them democratic states. [...] Now, in the aftermath of the Cold War, the United States is taking an entirely different approach to the loser of that conflict. Although it has offered financial assistance and friendship to Russia, the Clinton administration has made NATO expansion the centerpiece of its European policy.

[...] Hoy, en el nuevo orden generado tras la guerra fría, EE UU ha tomado una actitud completamente diferente a la del pasado respecto a los perdedores de aquel conflicto. Con el ofrecimiento de asistencia financiera y de amistad a Rusia, la Administración de Clinton ha hecho de la ampliación de la OTAN la pieza central de su política europea.

The correspondence for the progressive form is a present perfect in the Spanish translation. This entails a considerable change in the aspectual content of the message: what is described as an event in progress in the original is rendered as an event which has attained culmination and whose resulting state still holds. There are at least two potential reasons for this change. The first one is lexical, related to the actional type of the predicate. As evaluator D noted, there is a sense of the Spanish verb tomar 'take' which denotes an event that does not extend in time but which entails a change of state: once a decision has been taken, we see only its consequences. In the literature on aktionsart (types of actions that predicates may express when combined with their arguments), this actional type is called an achievement (e.g., see Vendler 1967, and Moens and Steedman 1987). Different actional types tend to co-occur with specific verb tenses. In the case of achievements, which make explicit the moment a change of state takes place, the present perfect (pretérito perfecto in Spanish) is more compatible than those tenses which signal the progression in time of the event. The combination of lexical aspect with verbal or sentence aspect may have played a significant role in the choice.

From a translational point of view, the correspondence progressive into present perfect is a legitimate solution if we assume the existence of a semantic or cognitive gap between SL and TL that can only be filled by what Vinay and Darbelnet (1958, 1995: 248) call a "change in point of view" or modulation. In their words, "in principle we could say that, generally, modulation articulates the contrast between two languages faced with the same situation but two different modes of thinking, by exposing this divergence in expression form." Aspect is a domain where such divergences are possible. Even if aspectual notions are universal, it is also true that languages often differ in the application of those aspectual perspectives to describe reality. In this particular example, it could be argued that the taking of a given approach is seen as an event which extends in time in English (therefore compatible with the progressive), whereas it is regarded as an achievement in Spanish (therefore not quite compatible with the progressive), with the focus on the result of the event rather than on the event itself. Interestingly, among the different modulation types 
Vinay and Darbelnet include "exchange of intervals for limits (in space and time)", which corresponds to the case where French expresses the limit of an interval where English expresses its duration.

The author of the published translation is not alone in his/her choice: informant-translator A also used the pretérito perfecto. In support of the idea that such differences in aspectual perspectives are not simply differences in individual usage of aspect is the fact that the same correspondence in a parallel case this time in a translation into Catalan. Specifically, informant-translator E in excerpt (7) above translated Companies are pulling out as Algunes companyies ja han marxat. 'some companies have already left'. The repetition of events of the same type, i.e. the gradual pulling out of a country by a group of companies one after another, is viewed as an event which extends in time (a process) in English and as such is compatible with the progressive. In Catalan, the focus is on the for now partial result of that series of events, i.e. that some companies have already left. This favours the occurrence of the present perfect rather than the progressive form.

Modulation is considered in translation handbooks as the supreme translation technique, "the touchstone of a good translator" (Vinay and Darbelnet 1995: 246). Nevertheless, there exist individual differences among translators in the extent to which they feel the need to apply it and among evaluators in the degree of approval. In the Spanish case discussed above, although the actional type as a lexical feature is an objectivisable factor that make it possible to predict the application of modulation, evaluators had contrasting opinions: evaluator D approved of the correspondence but evaluator $\mathrm{C}$ found that the translation of a process as a result did not convey the intention of the original, i.e. was semantically inadequate. Similarly, translator B used the word-for-word solution estar + gerund.

\section{Summary and Conclusions}

The approach followed by the informants both in translating and evaluating indicates that, among the language-related factors determining the verbal morphology to be used, the main one is the lexical choice of the predicate which supports the tense form, although structural, informational and discourse factors also play a role.

The lexical features that informants paid attention to are: (a) the actional type of the correspondence, which as we have seen in example (9) above determines the choice of the most compatible verb form in the target text; (b) the metaphorical import of the lexical item and/or its modifiers (e.g. sweep furiously in (3) above). In this case we can speculate that the whole translation strategy for that sentence is directed to solving it. A plausible result is that the rest of the information contained in the sentence, including tense and aspect, is subordinated to the solution of the lexical problem. In such a situation, although the metaphorical use is objective lexical information (frequently it is attested in dictionaries), the reaction of the translator to it and its effects on the translating process is subjective.

Another factor is the manipulation of the syntactic structure where the verb form occurs. The translator's choice of a different syntactic structure than that of the original may, in turn, be due to language restrictions such as the lack of the same structure in the TL, but also to normative restrictions such as the need to accommodate the TT to the syntactic patterns which are most frequent in the TL (as informant 
D suggests for example (6)). Assuming that language-related factors are intertwined with translational decisions, we can speculate that economy considerations can also affect the choice (e.g., if there is a restriction on the length of the text, knowing that Spanish translations are usually longer in words than the English originals would make the translator opt for shorter alternatives). Two instances of this are informant A's version of example (3), where a full relative clause is translated as an adjective phrase, causing the tense form to disappear and informant D's version of excerpt (6).

A third factor is the informational organisation of the proposition where the verb form occurs. If the translator chooses to package information differently than the original, the tense form associated may also be different (see discussion of example (6)).

The functions of the tense-aspect form in the discourse where it occurs and its role as a marker of genre also play a role. We have considered the possibility that the denominating function of the English progressive, which is based on its discourseanaphoric properties, is being extended to the durative periphrases of Catalan and Spanish, which originally and according to traditional grammar are aspect markers. Similarly, the use of the combination passive voice plus estar + gerund by translators of editorials may indicate the weight of genre-related strategies in translating.

As regards the methodology of the study, the feedback provided by the informants proves the observational adequacy of the segmentation methods in comparative research such as van Leuven-Zwart (1989: 155) where the unit of analysis or transeme is either a predicate (state of affairs transeme) or the predicate's adjuncts.

The informants as translators use certain strategies which we can interpret as related to the task's goals-priorities in the sense of the Priorities and Restrictions model (Zabalbeascoa 1998). In the present study, individual differences can be attributed to how the goal "provide as much a literal translation as the target language allows you to" was understood and achieved by each informant. As Zabalbeascoa (1998: 13) points out, "[the expression] literal translation is often ambiguous because it may be regarded as a priority, a method, or a type of solution".

For those translators whose idea of literal translation is homologous with Newmark's semantic translation (i.e. the preservation of the "exact contextual meaning of the original), the TL semantic and syntactic structures are an important restriction which can force them to provide solutions that are considered instances of oblique techniques. Modulation in the form of an aspectual shift (e.g. from an ongoing process to a resulting state) is a good example. The difference between a translator who opts for the the present perfect in Spanish (hence focusing on the resulting state) to render the present progressive of the English text, and a translator who opts for the formally parallel (i.e. literal) Spanish "durative" periphrasis is that the former feels a semantic restriction in his/her target language which has to be accounted for, whereas the latter does not. This can be a consequence of differences in their respective target language norms or a consequence of different translation styles. It is not far-fetched to conjecture that most translators expect the largest amount of manipulation to be required in the lexical elements of the text, and that fewer translators are aware of the potential changes in other elements contributing to the global sense of the sentence and the discourse such as the tense and aspect markers.

Finally, the concluding words are devoted to the defense of the study of linguistic form as a research tool in translation studies. 
The contrastive phenomena of the source and target languages have traditionally been considered objectivizable — using the term coined by Jumpelt (1961, translated and reprinted in Chesterman 1986: 33-36), i.e. they are linguistic realisations of a speech community predetermined by the language itself. Objectivizability implies, in Jumpelt's words, that "it should be possible to give them an adequate, semantically based description and compare them with other languages" (ibid.). This assumption has determined the role of the study of linguistic form in the broader framework of translation studies. In their survey of empirical translation studies, Dancette and Ménard (1996) say that most empirical linguistic studies neutralise as much as possible the variables related to the translator, and therefore contribute mainly to a better understanding of language (my emphasis), e.g. by pointing at the need for finer definitions of certain linguistic categories, by calling into question certain notions held by comparative stylistics but never actually proved, etc. The only exception is that of a few linguistic studies that have helped point at the difficulties encountered in recognising translation units as discrete units.

As we have seen in this paper, the use of the target language by a translator is influenced also by the translating task, which means that some linguistic facts are far from being absolute truths. Specifically, those grammar areas where the TL system has formal similarities, and at the same time differences, with the SL system are especially sensitive areas. If we add a situation of linguistic change and a certain degree of individual variation among native speakers, then we can no longer be sure that linguistic contrast is objectivizable only in linguistic terms.

\section{NOTES}

* The research reported here is financed in part by the Spanish government (DGICYT projects PB950985-C 03-01, PB98-1062-C04-01 and PB96-1199-C04-02).

1. So far we have been assuming a one-to-one mapping between progressive form and some sort of "progressive meaning", but strictly speaking there is no such mapping. First, there are several forms which can express progressive aspect in English. Secondly, while it is true that there is a universal aspectual notion "progressive aspect", it is also the case that the progressive form can express other meanings; in English these "derived" readings are mostly modal and depend heavily on the discourse situation; in other languages the progressive form can express aspectual notions such as the state which holds of an individual as the consequence of a change (Japanese), or habitual events (Bantu). One of the latest and most comprehensive definitions of the semantics of the English progressive is to be found in Asher (1992) and can be paraphrased as follows: from an utterance containing a verb in the progressive form the language user can infer that, taking as reference a contextually fixed period of time, the event expressed by that predicate is going to reach its completion in the future if things follow a normal course.

2. Some of those contexts are the scope of aspectual markers (e.g. the present perfect), the scope of modal verbs and those contexts which are potentially ambiguous between different readings of the simple present, e.g. actual event vs. habitual or generic events, actual event vs. imminent event (see examples in Lorenzo 1980, Gómez Torrego 1988, Espunya 1996).

3. The notions expressed by periphrases such as estar + gerund (also ir + gerund, acabar + de + inf) are not considered to be "grammatically distinguished categories" in the official grammar of the Spanish language (Alarcos Llorach 1994).

4. Here I am taking the-arguably naive-view that the translator acts as a neutral conveyor of the message addressed by the original editorialist to his/her target readers rather than as an interested manipulator of the original text seeking to persuade the reader of the target language newspaper's attempt to accept its political agenda. In other words, and using the functional typology of translation in Nord (1994), rather than translation as instrument, the published translations of editorials are taken here as instances of translation as document. In favour of this view are two observations: first of all, the fact that press review sections tend to contain several editorial pieces on the same 
topic often holding different opinions; secondly, the quality of the translations is not always as high as it would be necessary if these texts were indeed instrumental.

5. Personal communication of the person in charge of the section "Hemeroteca" of the Catalan daily Avui.

6. An instance of estar + gerund used anaphorically in discourse, (i) below, is given as an example of a calque from English. The book suggests the simple form in a different interrogative formulation (see (ic)).

(i) a. Are you telling me that ...?

b. m'est's dient que ...?

c. Qué dius/qué vols dir? (p. 80) what say-2 $2^{\text {nd }}-$ sing-pres/what want- $2^{\text {nd }}-$ sing-pres say-inf?

Anaphorical uses of estar + gerund are found also in Catalan original texts, although even in these cases we cannot discard the influence of English, possibly via Spanish.

7. It is an excerpt of the concluding paragraph of the editorial on Clinton's trip to Latin America, where the writer states the content of Clinton's message to the countries that he will visit, and gives him advice regarding what is best for the politics of his own country.

8. The progressive is used regardeless of the fact that the predicate expresses a metaphorical event (the forces of change are sweeping across the region) rather than a literal one (the region is changing).

\section{REFERENCES}

Alarcos Llorach, E. (1994): Gramática de la lengua española, Madrid, Espasa-Calpe.

Asher, N. (1992): "A default, truth conditional semantics for the progressive," Linguistics and Philosophy, 15, pp. 463-508.

CATford, J. C. (1965): A linguistic theory of translation, London, Oxford University Press.

Dancette, J. et N. MénARD (1996): «Modèles empiriques et expérimentaux en traductologie: Questions d'épistémologie», Meta, 41-1, p. 139-156.

Espunya, A. (1996): "Progressive Structures of English and Catalan," Ph.D. Dissertation, Barcelona, Universitat Autònoma de Barcelona.

García GonzÁlez, J. (1992): Perífrasis verbales, Madrid, Sociedad General Española de librería. Gómez Torrego, L. (1988): Perífrasis verbales, Madrid, Arco Libros.

Jumpelt, R. J. (1989): “On the objectivizability of translation,” Readings in Translation Theory (A. Chesterman, ed.) (excerpt translated and reprinted from R. J. Jumpelt (1961): Die Übersetzung naturwissenschafticher und technischer Literatur, Berlin, Langendscheit.).

KashKin, V. (1998): “Choice factors in translation,” Target, 10-1, pp. 95-110.

KöNIG, E. (1980): "On the context dependence of the progressive in English," Time, Tense and Quantifiers (RoHrer, ed.), Tübingen, Niemeyer.

Leuven-Zwart, K. van (1989): “Translation and original. Similarities and dissimilarities,” Target, 1-2, pp. 151-181.

López, J. G. y J. Minett (1997): Manual de traducción inglés-castellano, Barcelona, Gedisa.

LoRenzo, E. (1980): El español de hoy, lengua en ebullición, Madrid, Gredos.

LoRenzo, E. (1996): Anglicismos hispánicos, Madrid, Gredos.

MéLIs, G. (1997): «(BE +)-ING: glissements interprétatifs et contraintes», communication présentée à la Second Chronos Conference, Bruxelles (1997).

Newmark, P. (1988): Approaches to Translation, New York, Prentice Hall.

Nord, C. (1996): "El error en la traducción: categorías y evaluación", La enseñanza de la traducción (A. Hurtado, dir.), Castelló de la Plana, Publicacions de la Universitat Jaume I.

Pratt, C. (1980): El anglicismo en el español peninsular, Madrid, Gredos.

Quirk, R. and S. Greenbaum (1973): A University grammar of English, London, Longman.

RIVERs, W. L. et al. (1988): Writing for the media, Mountain View (Calif.), Mayfield.

Roca-Pons, J. (1958): “Estudios sobre las perífrasis verbales del español”, Madrid, Consejo Superior de Investigaciones Científicas.

Televisió de Catalunya, Comissió de Normalització Lingúistica (1995): El Catalá a TV3: llibre d'estil, Barcelona, Edicions 62. 
VAÑó-Cerdé, A. (1982): Ser y Estar + Adjetivos. Un estudio sincrónico y diacrónico, Tübingen, Gunter Narr Verlag.

VÁzquez Ayora, Gerardo (1977): Introducción a la traductología, Washington, Georgetown University Press.

Vinay, J.-P. and J. Darbelnet (1995): Comparative stylistics of French and English, Amsterdam, John Benjamins Publishing (transl. from Stylistique comparée de l'anglais et du français, 1958).

WandruszKa, M. (1976): Nuestros idiomas: comparables e incomparables, Madrid, Gredos (trad. de Unsere Sprache: Vergleichbar und Unvergleichbar, 1969, por Elena Bombín).

Zabalbeascoa, P. (1998): “Prioritizing translation,” Barcelona, Universitat Pompeu Fabra. 